\title{
Watermelon Seedling Growth, Fruit Yield, and Quality following Pretransplant Nutritional Conditioning
}

\author{
Jonathan R. Schultheis ${ }^{1}$ \\ Department of Horticultural Science, North Carolina State University, Raleigh, \\ NC 27695-7609 \\ Robert J. Dufault ${ }^{2}$ \\ Coastal Research and Education Center, Department of Horticulture, Clemson \\ University, 2865 Savannah Highway, Charleston, SC 29414
}

Additional index words. Citrullus lanatus, cucurbitaceae, transplant, hardening, seedless, triploid, melon, cucurbit, nitrogen, phosphorus

\begin{abstract}
Pretransplant nutritional conditioning (PNC) of transplants during greenhouse production may improve recovery from transplanting stress and enhance earliness and yield of watermelon [Citrullus lanatus (Thumb.) Matsum. \& Nakai]. Two greenhouse experiments (Expts. 1 and 2) and field experiments in South Carolina and North Carolina (Expt. 3) were conducted to evaluate $\mathrm{N}$ and P PNC effects on watermelon seedling growth and their effects on fruit yield and quality. 'Queen of Hearts' triploid and 'Crimson Sweet' diploid watermelon seedlings were fertilized with $\mathrm{N}$ from calcium nitrate at 25, 75, or 225 mg.liter ${ }^{-1}$ and $P$ from calcium phosphate at 5, 15, or 45 mg.liter $^{-1}$. In the greenhouse, most variation in the shoot fresh and dry weights, leaf count, leaf area, transplant height, and root dry weight in 'Queen of Hearts' and 'Crimson Sweet' was attributed to N. Cultivar interacted with $\mathbf{N}$, affecting all seedling growth variables, but not leaf area in Expt. 2. To a lesser extent, in Expt. 1, but not in Expt. 2, $P$ interacted with cultivar, $N$, or cultivar $\times N$ and affected shoot fresh and dry weights, leaf count and leaf area. In the field, transplant shock increased linearly with $\mathrm{N}$, regardless of cultivar or field location. The effect of PNC on plant growth diminished as the growing season progressed. For both cultivars at both locations, $\mathbf{N}$ and $P$ PNC did not affect time to first staminate flower, fruit set, fruit width or length, soluble solids concentration, or yield. Vining at Charleston for both cultivars was 2 days earlier when $N$ was at 75 rather than $25 \mathrm{mg}$.liter ${ }^{-1}$, without further change with the high $\mathrm{N}$ rate. At Clinton, the first pistillate flower was delayed linearly the higher the N rate for 'Crimson Sweet'. At Charleston, hollow heart in the 'Queen of Hearts' increased nearly 3 times when N PNC rate was tripled (from 75 or 225 mg.liter $^{-1}$ ), while $\mathrm{N}$ had no effect on hollow heart in 'Crimson Sweet'. In contrast, at Clinton, hollow heart in either cultivar was affected by $P$ PNC, not $N$. PNC with $25 N-5 P$ (in mg.liter-1) can be used to reduce seedling growth and produce a more compact plant for easier handling, yet not reduce fruit quality or yield.
\end{abstract}

Seedless watermelons are becoming more popular with consumers, and consumption is expected to increase (Elmstrom and Maynard, 1990). Seedless watermelons are highly sterile hybrid triploids ( $3 \mathrm{n}$ ) produced from crossing normal diploid (2n) and tetraploid (4n) parental lines (Mohr, 1986). Triploid watermelon seeds are more expensive and difficult to germinate than seeds of traditional diploid cultivars (Maynard, 1989). Therefore, trans-

Received for publication 31 Jan. 1994. Accepted for publication 11 July 1994. This research was funded in part by the North Carolina Agricultural Research Service (NCARS), Raleigh. Use of trade names in this publication does not imply endorsement by the NCARS of products named nor criticism of similar ones not mentioned. We thank Dennis Adams for his technical assistance in this work. The cost of publishing this paper was defrayed in part by the payment of page charges. Under postal regulations, this paper therefore must be hereby marked advertisement solely to indicate this fact.

${ }^{1}$ Assistant Professor.

${ }^{2}$ Associate Professor. plants are used to establish fields of seedless watermelon instead of direct seeding. Transplants also have the advantage of maturing sooner than direct-seeded plants (Ivanoff et al., 1960; Nettles, 1963; Vavrina et al., 1990). Depending on cultivar, transplants can also produce higher total yields than direct-seeded plants (Hall, 1989).

To our knowledge, nutritional requirements and hardening techniques for seedless watermelon transplants are not documented. However, for transplants of the seeded watermelon cultivar Crimson Sweet, the effects of ammonium ratios and $\mathrm{Ca}$ have been reported (Lamb et al., 1993). Nutrient withdrawal is the major hardening method used commercially to slow transplant growth until shipping can occur (Berl Thomas, Speedling, personal communication). Although hardening prepares seedlings to better withstand transplant shock (biotic and climatic), nutrient-hardened transplants may recover slower even when sufficient $\mathrm{N}$ is applied after transplanting (Aloni et al., 1991). Slow recovery from transplant shock at transplanting and nutrient hardening can negate early yields and result in missed early marketing opportunities.

Pretransplant nutritional conditioning (PNC) predisposes seedlings during the greenhouse production phase to recover quickly from stress encountered at transplanting and to yield earlier. PNC has been attempted on a variety of vegetable genera with positive results, including celery (Apium graveolens L.) (Dufault, 1985; Masson et al., 1991; Tremblay et al., 1987), broccoli (Brassica oleracea L. var. italica) and lettuce (Lactuca sativa L.) (Masson et al., 1991), and tomato (Lycopersicon esculentum Mill.) (Melton and Dufault, 1991; Weston and Zandstra, 1989). Muskmelon(Cucumis melo L. var. reticulatus) transplants conditioned with high levels of $\mathrm{N}$, $\mathrm{P}$, and $\mathrm{K}$ vined sooner and yielded earlier than those conditioned with low $\mathrm{N}, \mathrm{P}$, and $\mathrm{K}$ (Dufault, 1986). PNC has not been previously investigated on seedless watermelons.

The objectives of this research were to determine 1) the relative importance of $\mathrm{N}$ and $\mathrm{P}$ nutrient regimes on seedling growth of diploid and triploid watermelons and 2) the effects of transplant conditioning of diploid and triploid cultivars on early field growth, yield, and quality in two diverse locations, one in North Carolina and one in South Carolina.

\section{Materials and Methods}

Influence of $\mathbf{N}$ and $P$ PNC on seedling growth, North Carolina

Experiment 1. Seeds of the triploid cultivar Queen of Hearts were sown in plastic, ninecell, inverted-trapezoid containers (top, $4 \times 4$ $\mathrm{cm}$; bottom, $3 \times 3 \mathrm{~cm}$; depth, $5.4 \mathrm{~cm}$; cell volume, $65-\mathrm{cm}^{3}$ ) filled with Redi-Earth Peatlite mix (peat and vermiculite medium; W.R. Grace \& Co., Allentown, Pa.), on 5 Feb. 1991 at Raleigh, N.C. Similarly, seeds of the diploid cultivar Crimson Sweet were planted on 19 Feb. Soil tests showed the medium contained 1N-3P-108K (in mg.liter ${ }^{-1}$ ) with a $6.8 \mathrm{pH}$. Nutrient solutions consisted of factorial combinations of $\mathrm{N}$ from calcium nitrate at 25 (low), 75 (intermediate), or 225 (high) $\mathrm{mg}$ liter $^{-1}$ and $P$ from calcium phosphate at 5 (low), 15 (intermediate), or 45 (high) $\mathrm{mg}$ liter $^{-1}$. Since total Ca varied by $\mathrm{N}$ treatment and the highest $\mathrm{N}$ rate contained $347 \mathrm{mg} \mathrm{Ca} /$ liter, all treatment solutions were adjusted to $347 \mathrm{mg} \mathrm{Ca}$ /liter with calcium carbonate to avoid confounding by $\mathrm{Ca}$ effects. Each treatment solution also included the following: potassium sulfate at 100 mg.liter ${ }^{-1}$, magnesium sulfate at 70 mg. liter $^{-1}$; and micronutrients at 313 mg.liter ${ }^{-1}$ with STEM (Soluble Trace Element Mix; Peter's Fertilizer Products, W.R. Grace \& Co. $)(\mathrm{S}=15 \%, \mathrm{~B}$ $=1.45 \%, \mathrm{Cu}=3.2 \%, \mathrm{Fe}=7.5 \%, \mathrm{Mn}=8.2 \%$, $\mathrm{Mo}=0.46 \%, \mathrm{Zn}=4.5 \%$ ). The $\mathrm{pH}$ of the nutrient solutions was adjusted to 7.0 using $\mathrm{H}_{2} \mathrm{SO}_{4}$ or $\mathrm{NaOH}$, as needed. For the first 5 days after seeding, flats of 'Queen of Hearts' were placed in a greenhouse where average day and night temperatures were maintained at $27 \mathrm{C}$ to enhance seed germination. Six days after seeding, flats of 'Queen of Hearts' were moved to 
a greenhouse with an average day maximum of $27 \mathrm{C}$ and night minimum of 24C. 'Crimson Sweet' flats were placed in a greenhouse with a 27/24C day/night regime at seeding. Each treatment plot consisted of nine plants. The nine treatments were replicated four times and arranged in a randomized complete-block design.

Nutrients were first applied as a preplant drench the day of seeding and thereafter twice weekly for a total of seven applications. The cell packs were subirrigated with nutrient solution on 26-cm-diameter plastic plates for $1 \mathrm{~h}$, then drained of excess solution. The study ended on 6 Mar. and 15 Mar. for 'Queen of Hearts' and 'Crimson Sweet', respectively, 29 and 24 days after seeding.

At the end of the experiment, the following growth variables were measured: shoot fresh and dry weights; expanded true-leaf count (leaves with clearly visible petioles); leaf area, including petiole, with a leaf area meter (LICOR, Lincoln, Neb.); and washed root dry weights (dried for $24 \mathrm{~h}$ at $65 \mathrm{C}$ ). Leaf count was transformed before analysis (Little, 1985). Data were analyzed using analysis of variance (ANOVA). The relative importance of $\mathrm{N}, \mathrm{P}$, and cultivar and their interactions was determined by partitioning the total sum of squares for the model (composed of only those sources of variation in the ANOVA). If main or interaction effects were significant, regression analysis was used to indicate significant trends.

Experiment 2. The nutrition study was repeated using cultivar, $\mathrm{N}$, and $\mathrm{P}$ as factors. 'Crimson Sweet' and 'Queen of Hearts' watermelon seeds were planted on 24 Apr. 1991 at Raleigh and placed in a greenhouse with an average day maximum of $27 \mathrm{C}$ and night minimum of $24 \mathrm{C}$

The rates and sources of $\mathrm{N}$ and $\mathrm{P}$ were the same as in Expt. 1. Magnesium, $\mathrm{Ca}$, and $\mathrm{pH}$ levels were adjusted as in Expt. 1. Each treatment plot consisted of four plants for growth analysis and 16 plants for field plantings (six plants for Charleston, S.C., 10 for Clinton, N.C.). Each treatment plot was replicated four times in a randomized complete-block design.

The first PNC treatment was applied as a preplant drench on 4 Apr. Thereafter, the nine PNC treatments were subirrigated twice weekly. Greenhouse cultural practices, data collection, and statistical analysis were the same as in Expt. 1, except plant height was determined (measured from medium surface to apical meristem). The greenhouse experiment was terminated 20 May, 26 days after seeding.

\section{Effect of $\mathrm{N}$ and $\mathrm{P}$ PNC during transplant production on response during field production (Expt. 3)}

Charleston site. The soil type was a Yauhannah loamy fine sand (Aquic Hapludults). The field was broadcast-fertilized with $75 \mathrm{~N}-34 \mathrm{P}-66 \mathrm{~K}$ (in $\mathrm{kg} \cdot \mathrm{ha}^{-1}$ ) before planting on bare ground. Watermelon transplants, grown in Raleigh, N.C., were transported to Charleston, S.C., by car on 22 May. Field planting was delayed at Charleston be- cause of extremely wet fields. The transplants were placed in darkness at $11 \mathrm{C}$ for 4 days to slow growth, then moved outdoors in a shaded area $3 \mathrm{~h}$ before field planting. Planting was on 28 May at the Clemson Univ. Coastal Research and Education Center, Charleston, S.C. Plants were spaced $1.4 \mathrm{~m}$ apart within rows on beds separated by $1.8 \mathrm{~m}$. Each treatment was replicated four times in a randomized complete-block design, and each plot contained six plants. The field was sidedressed with $50 \mathrm{~N}-$ 45P-88K (in $\mathrm{kg} \cdot \mathrm{ha}^{-1}$ ) on 18 June. Standard commercial pesticides were used to control insects and disease (Cook, 1991).

The incidence of transplant stress was evaluated 10 days after transplanting by counting the number of necrotic and healthy leaves. Days to vining (when first branch touched ground), detection of first staminate and pistillate flowers, and first fruit set were evaluated for three consecutive plants within each test row three times weekly. All marketable fruit were harvested on 5 Aug. because vines declined due to wet weather and nearly all fruit were mature. All fruit were graded into U.S. Fancy, number 1 and 2 quality categories (U.S. Dept. of Agriculture, 1978). Two marketable fruit per plot were evaluated for internal quality attributes: white heart, hollow heart, melon length and width, and soluble solids concentration (SSC) (with a hand-held refractometer). Data were analyzed as in Expt. 1. All percentage and count data were transformed (Little, 1985)

Clinton site. The soil type was an Orangeburg loamy sand, a Typic Paleudults. Ten plants per treatment per replication were hand-planted in the field on 22 May at the Horticultural Crops Research Station in Clinton, N.C., and were spaced $1.2 \mathrm{~m}$ apart within rows on beds separated by $1.5 \mathrm{~m}$. Each treatment was replicated four times in a randomized complete-block design. The field was broadcast with $56 \mathrm{~N}-56 \mathrm{P}-112 \mathrm{~K}$ (in kg.ha ${ }^{-1}$ ) on 5 May and sidedressed with $34 \mathrm{~kg} \mathrm{~N} / \mathrm{ha}$ on 28 May. Standard commercial pesticides were used to control insects and disease (College of Agriculture and Life Sciences, 1991).

The number of necrotic leaves (leaves present 10 days after transplanting), days to first staminate and pistillate flower, and days to first fruit set were evaluated as at the Charleston site. These data were transformed before analysis (Little, 1985). All marketable-size fruit were harvested on 5 Aug. and graded as either marketable or cull (U.S. Dept. of Agriculture, 1978) because vines declined due to wet weather and nearly all fruit were mature. Two marketable fruit per plot were evaluated for size and internal quality attributes: hollow heart, melon length and width, and SSC. All data were analyzed as in Expt. 1.

\section{Results and Discussion}

\section{Influence of $\mathrm{N}$ and $\mathrm{P}$ PNC on seedling growth, North Carolina}

Experiment 1. Most of the variation affecting seedling growth of 'Queen of Hearts' and 'Crimson Sweet' was attributed to the main effect of $\mathrm{N}$, with lesser amounts assigned to $\mathrm{P}$ and interactions (Table 1). This outcome was similar to that reported on muskmelon (Dufault, 1986). Cultivar interacted with $\mathrm{N}$, affecting all seedling growth variables, and, to a lesser extent, with $\mathrm{P}$ for leaf area and $\mathrm{N} \times \mathrm{P}$ interaction for fresh and dry shoot weights. Nitrogen has been shown to be of major importance in transplant fertility in previous reports. 'PikRed' tomato yielded earlier as N PNC increased from 100 to $400 \mathrm{mg} \cdot \mathrm{liter}^{-1}$ (Weston and Zanstra, 1989). Similarly, 'Springset' tomato yielded earlier as $\mathrm{N}$ levels increased to $400 \mathrm{mg} \cdot$ liter $^{-1}$ when N PNC was applied in two Canadian field studies (Masson et al., 1991). A deficiency in $\mathrm{N}$ during bell pepper transplant production reduced earliness, while excessive $\mathrm{N}$ delayed and reduced yield (Knavel, 1977).

Nitrogen and P interacted with cultivar for shoot fresh and dry weight variables (Table 2). At high P, 'Queen of Hearts' shoot fresh weight increased curvilinearly as $\mathrm{N}$ increased from low to high levels. At low and intermediate $\mathrm{P}$ levels, increasing $\mathrm{N}$ rate had no effect. As $\mathrm{N}$ rate increased from low to high levels, 'Queen of Hearts' shoot dry weight increased curvilinearly for each P level. With 'Crimson Sweet', shoot fresh and dry weights increased linearly as $\mathrm{N}$ levels increased, but at the high $\mathrm{P}$ level only. At low and intermediate P levels, these weights increased curvilinearly as $\mathrm{N}$ increased from the low to the high level.

Leaf count of both cultivars, regardless of $\mathrm{P}$ level, increased curvilinearly as $\mathrm{N}$ increased from the low to the high level (Table 2). At the intermediate $\mathrm{N}$ level, leaf count increased linearly as $\mathrm{P}$ levels increased, while at the high $\mathrm{N}$ level, leaf count increased curvilinearly as $\mathrm{P}$ increased from the low to the high level. Leaf area of both cultivars responded curvilinearly to $\mathrm{N}$ rates with increased growth from low to intermediate levels, without further effect with high $\mathrm{N}$ level. With both cultivars, leaf area increased linearly at the high $\mathrm{N}$ rate with increasing $\mathrm{P}$ rate. At low and intermediate $\mathrm{N}$ levels, increasing $\mathrm{P}$ rate did not affect leaf area.

Regardless of PNC, 'Crimson Sweet' seedlings were larger than 'Queen of Hearts'. The lesser growth of 'Queen of Hearts' seedlings may be attributed to increased difficulty in germinating triploid seeds and slower seedling emergence (Maynard, 1991). Leaf count and area for each cultivar responded similarly to $\mathrm{N}$ (Table 3). As $\mathrm{N}$ rate increased for each cultivar, leaves per seedling increased linearly. Leaf area for both cultivars responded curvilinearly to $\mathrm{N}$ rates with increased growth from the low to the intermediate rate, without further response at the high rate. Root dry weight of both cultivars responded differently to N. Root growth in 'Queen of Hearts' was unresponsive to N; however, 'Crimson Sweet' root dry weight increased as $\mathrm{N}$ increased from low to intermediate levels, without further effect with high $\mathrm{N}$. The differences in root growth of 'Crimson Sweet' and 'Queen of Hearts' is unexplained; however, seedless watermelons inherently have much weaker root systems than seeded cultivars.

Experiment 2. Most of the variation in 
Table 1. Sources of variation in the analysis of variance for the effects of N and P PNC and cultivar $(\mathrm{Cv})$ on 'Queen of Hearts' and 'Crimson Sweet' watermelon seedling growth. Experiment 1.

\begin{tabular}{|c|c|c|c|c|c|}
\hline \multirow{2}{*}{$\begin{array}{l}\text { Source of } \\
\text { variation }^{z}\end{array}$} & \multicolumn{2}{|c|}{ Shoot wt (g) } & \multirow{2}{*}{$\begin{array}{c}\text { No. } \\
\text { leaves/ } \\
\text { seedling }\end{array}$} & \multirow{2}{*}{$\begin{array}{l}\text { Leaf } \\
\text { area } \\
\left(\mathrm{cm}^{2}\right)\end{array}$} & \multirow{2}{*}{$\begin{array}{l}\text { Root } \\
\text { dry wt } \\
\text { (mg) }\end{array}$} \\
\hline & Fresh & Dry & & & \\
\hline Replication & $2^{* *}$ & $3^{* * *}$ & $9^{* *}$ & $8^{* *}$ & $3^{* *}$ \\
\hline $\mathrm{Cv}$ & $44^{* *}$ & $69^{* *}$ & $19^{* *}$ & $10^{* *}$ & $78^{* *}$ \\
\hline $\mathrm{N}$ & $30^{* *}$ & $17^{* *}$ & $42^{* *}$ & $52^{* *}$ & $4^{* *}$ \\
\hline $\mathrm{Cv} \times \mathrm{N}$ & $14^{* *}$ & $6^{* *}$ & $5^{* *}$ & $17^{* *}$ & $7^{* *}$ \\
\hline $\mathrm{P}$ & $2^{* *}$ & 0 & $4^{* *}$ & $2^{* *}$ & 1 \\
\hline $\mathrm{Cv} \times \mathrm{P}$ & $2^{* *}$ & 0 & 0 & $2^{* *}$ & 0 \\
\hline $\mathrm{N} \times \mathrm{P}$ & $2^{* *}$ & 0 & $4^{*}$ & $3^{* *}$ & 0 \\
\hline $\mathrm{Cv} \times \mathrm{N} \times \mathrm{P}$ & $1^{* *}$ & $1^{*}$ & 0 & 1 & 1 \\
\hline Error & 3 & 4 & 17 & 5 & 6 \\
\hline
\end{tabular}

${ }^{\mathrm{z}}$ Sum of squares for each factor converted to a percentage of total sum of squares.

${ }^{*}, * *$ Significant at $P \leq 0.05$ or 0.01 , respectively.

Table 2. Interaction of N and P PNC on 'Queen of Hearts' and 'Crimson Sweet' seedling growth in the greenhouse 29 and 24 days after seeding, respectively, and seven nutritional conditioning cycles in Expt. 1.

\begin{tabular}{|c|c|c|c|c|c|}
\hline \multirow[b]{2}{*}{ Cultivar } & \multirow{2}{*}{$\begin{array}{c}\mathrm{N} \\
\left(\mathrm{mg}^{\prime} \text { liter }^{-1}\right)\end{array}$} & \multicolumn{3}{|c|}{$\mathrm{P}\left(\mathrm{mg} \cdot\right.$ liter $\left.^{-1}\right)$} & \multirow[b]{2}{*}{ Significance $^{z}$} \\
\hline & & 5 & 15 & 45 & \\
\hline \multicolumn{6}{|c|}{ Shoot fresh wt ( $g$ ) } \\
\hline \multirow[t]{3}{*}{ Queen of Hearts } & 25 & 2.9 & 2.8 & 2.8 & NS \\
\hline & 75 & 3.4 & 3.2 & 3.4 & NS \\
\hline & 225 & 3.1 & 3.2 & 3.3 & NS \\
\hline Significance ${ }^{y}$ & & NS & NS & $\mathrm{Q}^{* *}$ & \\
\hline \multirow[t]{3}{*}{ Crimson Sweet } & 25 & 3.2 & 3.2 & 3.3 & NS \\
\hline & 75 & 4.7 & 5.1 & 5.0 & $\mathrm{Q}^{*}$ \\
\hline & 225 & 4.7 & 5.8 & 6.3 & $\mathrm{Q}^{*}$ \\
\hline \multirow[t]{2}{*}{ Significance } & & $\mathrm{Q}^{* *}$ & $\mathrm{Q}^{* *}$ & $\mathrm{~L}^{* *}$ & \\
\hline & & Shoot & & & \\
\hline \multirow[t]{3}{*}{ Queen of Hearts } & 25 & 1.7 & 1.7 & 1.8 & NS \\
\hline & 75 & 2.1 & 2.0 & 2.1 & NS \\
\hline & 225 & 2.0 & 2.0 & 2.0 & NS \\
\hline Significance & & $\mathrm{Q}^{* *}$ & $\mathrm{Q}^{* *}$ & $\mathrm{Q}^{* *}$ & \\
\hline \multirow[t]{3}{*}{ Crimson Sweet } & 25 & 2.6 & 2.5 & 2.6 & NS \\
\hline & 75 & 3.3 & 3.5 & 3.5 & NS \\
\hline & 225 & 3.5 & 3.9 & 4.1 & $\mathrm{Q}^{* *}$ \\
\hline \multirow[t]{2}{*}{ Significance } & & $\mathrm{Q}^{* *}$ & $\mathrm{Q}^{* *}$ & $\mathrm{~L}^{* *}$ & \\
\hline & \multicolumn{4}{|c|}{ Leaves/seedling } & \\
\hline \multirow{4}{*}{$\begin{array}{l}\text { Mean of both } \\
\text { cultivars }\end{array}$} & & & & & \\
\hline & 25 & 3.3 & 3.2 & 3.3 & NS \\
\hline & 75 & 3.5 & 3.6 & 3.8 & $\mathrm{~L}^{* * *}$ \\
\hline & 225 & 3.6 & 3.8 & 3.8 & $\mathrm{Q}^{* *}$ \\
\hline \multirow[t]{2}{*}{ Significance } & & $\mathrm{Q}^{*}$ & $\mathrm{Q}^{* *}$ & $\mathrm{Q}^{* *}$ & \\
\hline & \multicolumn{4}{|c|}{ Leaf area $\left(\mathrm{cm}^{2}\right)$} & \\
\hline \multirow{4}{*}{$\begin{array}{l}\text { Mean of both } \\
\text { cultivars }\end{array}$} & & & & & \\
\hline & 25 & 51 & 49 & 50 & NS \\
\hline & 75 & 67 & 69 & 71 & NS \\
\hline & 225 & 66 & 75 & 79 & $\mathrm{~L}^{* *}$ \\
\hline Significance & & $\mathrm{Q}^{* *}$ & $\mathrm{Q}^{* *}$ & $\mathrm{Q}^{* *}$ & \\
\hline
\end{tabular}

Table 3. Influence of N PNC on 'Queen of Hearts' and 'Crimson Sweet' watermelon seedling growth. Experiment 1.

\begin{tabular}{|c|c|c|c|c|}
\hline Cultivar & $\begin{array}{c}\mathrm{N} \\
\left(\mathrm{mg} \cdot \text { liter }^{-1}\right)\end{array}$ & $\begin{array}{c}\text { No. } \\
\text { leaves/ } \\
\text { seedling }\end{array}$ & $\begin{array}{l}\text { Leaf area } \\
\left(\mathrm{cm}^{2}\right)\end{array}$ & $\begin{array}{c}\text { Root } \\
\text { dry wt } \\
(\mathrm{mg})\end{array}$ \\
\hline \multirow[t]{3}{*}{ Queen of Hearts } & 25 & 3.2 & 53 & 119 \\
\hline & 75 & 3.5 & 64 & 112 \\
\hline & 225 & 3.5 & 62 & 108 \\
\hline Significance & & $\mathrm{L}^{* * *}$ & $\mathrm{Q}^{* *}$ & NS \\
\hline \multirow[t]{3}{*}{ Crimson Sweet } & 25 & 3.3 & 47 & 222 \\
\hline & 75 & 3.8 & 73 & 313 \\
\hline & 225 & 3.9 & 85 & 328 \\
\hline Significance & & $\mathrm{L}^{* *}$ & $\mathrm{Q}^{* *}$ & $\mathrm{Q}^{*}$ \\
\hline
\end{tabular}

seedling growth was attributed to N PNC, with P having no effect, unlike in Expt. 1 (Table 4). Shoot and root dry weights in Expt. 2 were greater than in Expt. 1. The later planting date and longer growth period (4 days) may have increased seedling growth. Cultivars interacted with $\mathrm{N}$ for each seedling growth variable, except leaf area.

Shoot fresh weight increased curvilinearly with $\mathrm{N}$ for both cultivars, with growth increasing from low to intermediate levels, without further effect at the highest concentration (Table 5). Shoot dry weight and leaf count increased linearly in both cultivars with increasing $\mathrm{N}$ rates. Seedling height increased linearly for 'Queen of Hearts' with increasing N rate; however, height increased curvilinearly for 'Crimson Sweet' with increasing N. These differences between cultivars may be attributed to greater growth by 'Crimson Sweet', as in Expt. 1. Root dry weight of 'Queen of Hearts' was unaffected by N PNC, also as in Expt. 1; however, 'Crimson Sweet' root dry weight increased linearly with increasing $\mathrm{N}$ rate. Leaf area for both cultivars increased linearly as $\mathrm{N}$ rates increased.

Based on these two experiments, watermelon seedling growth for both cultivars was most vigorous at $225 \mathrm{mg} \mathrm{N} / \mathrm{liter}$ and $45 \mathrm{mg} \mathrm{P} /$ liter, at constant $\mathrm{K}$ of $100 \mathrm{mg} \cdot \mathrm{liter}^{-1}$.

\section{Effect of $N$ and $P$ PNC during transplant production on response during field production (Expt. 3).}

Transplant shock and preharvest growth. Most of the variation from treatment effects in necrotic leaves or transplant shock of both cultivars in each location was attributed to N, while $\mathrm{P}$ and interactions had no significant effect (Table 6). Air minima at Clinton were lower than Charleston for 8 days following transplanting (up to $9 \mathrm{C}$ lower). Air maxima increased over time at Clinton (mean $=31 \mathrm{C}$ ), but remained consistently higher in Charleston $($ mean $=32 \mathrm{C}$ ) during the period of the experiment. In both locations, transplant shock, expressed as incidence of leaf necrosis, increased linearly with increasing $\mathrm{N}$, regardless of cultivar, and was highest with high $\mathrm{N}$. Although the transplants at Charleston encountered higher temperatures than at Clinton, the percentage of necrotic leaves at the high $\mathrm{N}$ rate was similar in both locations. Holding the transplants in Charleston in a dark cooler (11C) for 4 days apparently did not increase the incidence of transplant shock in contrast to immediate field planting at Clinton.

The effect of PNC on plant growth diminished as the growing season progressed. Nitrogen contributed most to the variation in vining at Charleston and time to first pistillate flower at Clinton, but $\mathrm{P}$ did not affect vining or flowering at either location or for either cultivar (Table 7). For both cultivars grown in Charleston, as $\mathrm{N}$ increased from the low to the intermediate levels, vining was 2 days earlier, without any advantage with the high $\mathrm{N}$ rate. In contrast, the first pistillate flower in 'Crimson Sweet' at Clinton was delayed up to 3 days with increasing N. Nitrogen had no significant 
Table 4. Sources of variation in the analysis of variance for the effects of $\mathrm{N}$ and P PNC and cultivar (Cv) on 'Queen of Hearts' and 'Crimson Sweet' watermelon seedling growth. Experiment 2.

\begin{tabular}{|c|c|c|c|c|c|c|}
\hline \multirow{2}{*}{$\begin{array}{l}\text { Source of } \\
\text { variation }^{2}\end{array}$} & \multicolumn{2}{|c|}{ Shoot wt (g) } & \multirow{2}{*}{$\begin{array}{c}\text { Seedling } \\
\text { ht } \\
(\mathrm{cm})\end{array}$} & \multirow{2}{*}{$\begin{array}{c}\text { No. } \\
\text { leaves/ } \\
\text { seedling }\end{array}$} & \multirow{2}{*}{$\begin{array}{l}\text { Leaf } \\
\text { area } \\
\left(\mathrm{cm}^{2}\right)\end{array}$} & \multirow{2}{*}{$\begin{array}{c}\text { Root dry } \\
\text { wt } \\
(\mathrm{mg})\end{array}$} \\
\hline & Fresh & Dry & & & & \\
\hline Replication & 0 & 1 & 0 & $4^{* *}$ & 0 & 3 \\
\hline $\mathrm{Cv}$ & $7^{* *}$ & $9^{* * *}$ & $3^{* *}$ & 0 & 1 & 0 \\
\hline $\mathrm{N}$ & $79^{* *}$ & $58^{* *}$ & $76^{* *}$ & $77^{* * *}$ & $85^{* *}$ & 7 \\
\hline $\mathrm{Cv} \times \mathrm{N}$ & $4^{* *}$ & $4^{* *}$ & $6^{* *}$ & $3^{* *}$ & 1 & $13^{*}$ \\
\hline $\mathrm{P}$ & 0 & 1 & 2 & 0 & 1 & 2 \\
\hline $\mathrm{Cv} \times \mathrm{P}$ & 0 & 2 & 0 & 2 & 0 & 1 \\
\hline $\mathrm{N} \times \mathrm{P}$ & 0 & 1 & 0 & 1 & 1 & 8 \\
\hline $\mathrm{Cv} \times \mathrm{N} \times \mathrm{P}$ & 0 & 2 & 0 & 1 & 1 & 6 \\
\hline Error & 12 & 22 & 13 & 12 & 10 & 60 \\
\hline
\end{tabular}

${ }^{2}$ Sum of squares for each factor converted to a percentage of total sum of squares.

*,** Significant at $P \leq 0.05$ or 0.01 , respectively.

Table 5. Influence of N PNC on 'Queen of Hearts' and 'Crimson Sweet' watermelon seedling growth. Experiment 2.

\begin{tabular}{|c|c|c|c|c|c|c|c|}
\hline \multirow[b]{2}{*}{ Cultivar } & \multirow{2}{*}{$\begin{array}{c}\mathrm{N} \\
\left(\mathrm{mg} \cdot \mathrm{liter}^{-1}\right)\end{array}$} & Sho & $(\mathrm{g})$ & \multirow{2}{*}{$\begin{array}{c}\text { No. } \\
\text { leaves/ } \\
\text { seedling }\end{array}$} & \multirow{2}{*}{$\begin{array}{c}\text { Seedling } \\
\text { ht } \\
(\mathrm{cm})\end{array}$} & \multirow{2}{*}{$\begin{array}{c}\text { Root dry } \\
\text { wt } \\
(\mathrm{mg})\end{array}$} & \multirow{2}{*}{ 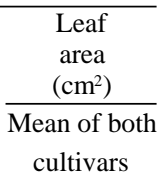 } \\
\hline & & Fresh & Dry & & & & \\
\hline \multirow[t]{3}{*}{ Queen of Hearts } & 25 & 3.1 & 1.4 & 2.7 & 10.4 & 196 & 46 \\
\hline & 75 & 5.1 & 2.3 & 3.3 & 16.7 & 193 & 74 \\
\hline & 225 & 7.1 & 2.9 & 3.6 & 19.8 & 190 & 112 \\
\hline Significance & & $\mathrm{Q}^{*}$ & $\mathrm{~L}^{* *}$ & $\mathrm{~L}^{* *}$ & $\mathrm{~L}^{* *}$ & NS & $\mathrm{L}^{* *}$ \\
\hline \multirow[t]{3}{*}{ Crimson Sweet } & 25 & 3.5 & 1.7 & 2.7 & 10.3 & 162 & --- \\
\hline & 75 & 6.0 & 2.7 & 3.2 & 16.8 & 203 & --- \\
\hline & 225 & 9.6 & 4.2 & 3.8 & 25.8 & 236 & --- \\
\hline Significance & & $\mathrm{Q}^{*}$ & $\mathrm{~L}^{* *}$ & $\mathrm{~L}^{* * *}$ & $\mathrm{Q}^{* *}$ & $\mathrm{~L}^{* *}$ & --- \\
\hline
\end{tabular}

Ns, ${ }^{*},{ }^{* *} \mathrm{~F}$ test nonsignificant or significant at $P \leq 0.05$ or 0.01 , respectively; $\mathrm{L}=$ linear and $\mathrm{Q}=$ quadratic effect. Indicates significance of increasing $\mathrm{N}$ rate pooled over all $\mathrm{P}$ rates for each cultivar.

effect on flowering in 'Queen of Hearts'.

Yield and quality. Nitrogen and P PNC affected some fruit quality variables at both locations (Tables 8 and 9) but not melon length, width, or SSC (data not shown). At Charleston, the percentage of fruit with white heart increased curvilinearly as $\mathrm{N}$ increased from the low to high rate (Table 8). There was nearly 3 times more hollow heart in 'Queen of Hearts' as the $\mathrm{N}$ rate increased. Nitrogen did

Table 6. Effect of N PNC on incidence of leaf necrosis, as the percentage of leaves affected on 'Crimson Sweet' and 'Queen of Hearts' watermelon plants, determined 10 days after transplanting at Clinton, N.C., and Charleston, S.C. Experiment 3.

\begin{tabular}{|c|c|c|}
\hline \multirow{2}{*}{$\begin{array}{l}\mathrm{N} \\
\left(\mathrm{mg} \cdot \text { liter }^{-1}\right)\end{array}$} & \multicolumn{2}{|c|}{ Leaf necrosis } \\
\hline & Clinton & Charleston \\
\hline 25 & 23 & 28 \\
\hline 75 & 34 & 31 \\
\hline 225 & 37 & 38 \\
\hline Significance & $\mathrm{L}^{* *}$ & $\mathrm{~L}^{* *}$ \\
\hline \multicolumn{3}{|c|}{ Source of variation ${ }^{\mathrm{z}}$} \\
\hline Replication & 5 & $13^{* *}$ \\
\hline Cultivar (Cv) & 1 & 0 \\
\hline $\mathrm{N}$ & $27^{* *}$ & $15^{* *}$ \\
\hline $\mathrm{Cv} \times \mathrm{N}$ & 5 & 3 \\
\hline $\mathrm{P}$ & 1 & 0 \\
\hline $\mathrm{Cv} \times \mathrm{P}$ & 0 & 5 \\
\hline $\mathrm{N} \times \mathrm{P}$ & 2 & 3 \\
\hline $\mathrm{Cv} \times \mathrm{N} \times \mathrm{P}$ & 3 & 2 \\
\hline Error & 56 & 59 \\
\hline
\end{tabular}

${ }^{\mathrm{z}}$ Sum of squares for each factor converted to a percentage of total sum of squares.

${ }^{* *} \mathrm{~F}$ test significant at $P \leq 0.01 ; \mathrm{L}=$ linear and $\mathrm{Q}=$ quadratic effects. Indicates significance of increasing $\mathrm{N}$ rate pooled over all $\mathrm{P}$ rates for both cultivars. heart in 'Crimson Sweet' at Charleston (data not shown). Generally, the incidence of hollow heart is greater in triploid than diploid watermelons (Henderson, 1977). The difference in response between locations indicates that, in addition to cultivar and PNC, environment may also play a substantial role in the expression of hollow heart.

At Charleston, with 'Queen of Hearts', no differences occurred in the percentage of fancy fruit due to P level (Table 9). With 'Crimson Sweet', the percentage of fancy fruit increased curvilinearly with increasing P. The percentage of number 2 fruit of both cultivars decreased curvilinearly as $\mathrm{P}$ increased from the low to high rate, with a $14 \%$ decrease from the intermediate to high rate. All other quality variables measured were unaffected by $\mathrm{N}$ and P PNC in both locations (data not shown).

The $\mathrm{N}$ and $\mathrm{P}$ treatments given during transplant production did not affect 'Queen of Hearts' and 'Crimson Sweet' yield in either location (data not shown). Average marketable yield pooled over all treatments at Clinton for 'Queen of Hearts' was 7300 fruit/ha and 4300 fruit/ha for 'Crimson Sweet'. At Charleston, average marketable yield was 5700 fruit/ ha for 'Queen of Hearts' and 2800 fruit/ha for 'Crimson Sweet'. Although transplant shock increased with increased N PNC, the plants recovered and yielded similarly for seedlings grown with the lowest $\mathrm{N}$ and P PNC treatment.

Summary. Shoot fresh and dry weight, leaf count, leaf area, root dry weight, and plant height responses differed in 'Crimson Sweet' and 'Queen of Hearts' seedlings conditioned with high $\mathrm{N}$ and $\mathrm{P}\left(225 \mathrm{~N}-45 \mathrm{P}\right.$, in mg.liter $\left.{ }^{-1}\right)$ compared with low $\mathrm{N}$ and $\mathrm{P}(25 \mathrm{~N}-5 \mathrm{P}$, in mg.liter ${ }^{-1}$ ). Transplant shock was greater when seedlings were conditioned with high N PNC regimes, but yield was unaffected by transplant nutrition in North Carolina and South Carolina. Although quality was somewhat affected by PNC in both locations, PNC had no major advantage, unlike in other crops. The results from this study suggest that low $\mathrm{N}$ and

Table 7. Effect of N PNC on growth of 'Crimson Sweet' and 'Queen of Hearts' watermelon plants in the field at Charleston, S.C., and Clinton, N.C. Experiment 3.

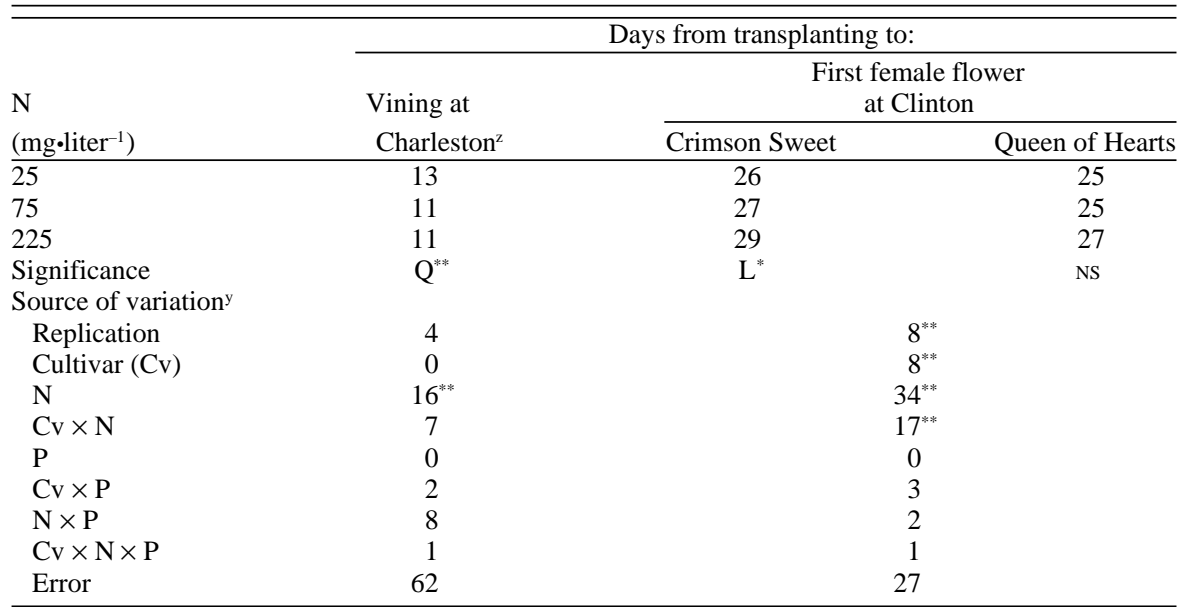

${ }^{\mathrm{z}}$ Mean of both cultivars.

${ }^{y}$ Sum of squares for each factor converted to a percentage of total sum of squares.

${ }_{\text {ns, }, * *} \mathrm{~F}$ test nonsignificant or significant at $P \leq 0.05$ or 0.01 , respectively; $\mathrm{L}=$ linear and $\mathrm{Q}=$ quadratic effect. Indicates significance of increasing $\mathrm{N}$ rate pooled over all $\mathrm{P}$ rates. 
Table 8. Effect of N PNC on quality of 'Crimson Sweet' and 'Queen of Hearts' watermelon plants at Charleston, S.C. Experiment 3.

\begin{tabular}{|c|c|c|c|}
\hline \multirow[b]{2}{*}{ Cultivar } & \multirow[b]{2}{*}{$\underset{\left(\mathrm{mg} \cdot \text { liter }^{-1}\right)}{\mathrm{N}}$} & \multirow{2}{*}{$\begin{array}{c}\text { White heart } \\
\frac{(\%)}{\text { Mean of both }} \\
\text { cultivars }\end{array}$} & \multirow[b]{2}{*}{$\begin{array}{l}\text { Hollow heart } \\
(\%)\end{array}$} \\
\hline & & & \\
\hline \multirow[t]{3}{*}{ Queen of Hearts } & 25 & 0 & 17 \\
\hline & 75 & 10 & 13 \\
\hline & 225 & 6 & 38 \\
\hline Significance & & $\mathrm{Q}^{*}$ & $\mathrm{Q}^{* *}$ \\
\hline \multirow[t]{3}{*}{ Crimson Sweet } & 25 & -- & 0 \\
\hline & 75 & --- & 4 \\
\hline & 225 & --- & 8 \\
\hline Significance & & & NS \\
\hline \multicolumn{4}{|c|}{ Source of variation ${ }^{z}$} \\
\hline Replication & & 2 & 1 \\
\hline Cultivar (Cv) & & $9^{* *}$ & $15^{* *}$ \\
\hline $\mathrm{N}$ & & $10^{*}$ & 6 \\
\hline $\mathrm{Cv} \times \mathrm{N}$ & & 4 & $7^{*}$ \\
\hline $\mathrm{P}$ & & 2 & 1 \\
\hline $\mathrm{Cv} \times \mathrm{P}$ & & 5 & 3 \\
\hline $\mathrm{N} \times \mathrm{P}$ & & 5 & 7 \\
\hline $\mathrm{Cv} \times \mathrm{N} \times \mathrm{P}$ & & 9 & 5 \\
\hline Error & & 54 & 55 \\
\hline
\end{tabular}

${ }^{2}$ Sum of squares for each factor converted to a percentage of total sum of squares.

Ns, ${ }^{* * * *} \mathrm{~F}$ test nonsignificant or significant at $P \leq 0.05$ or 0.01 , respectively; $\mathrm{L}=$ linear and $\mathrm{Q}=$ quadratic effect. Indicates significance of increasing $\mathrm{N}$ rate pooled over all $\mathrm{P}$ rates.

Table 9. Effect of P PNC on quality of 'Crimson Sweet' and 'Queen of Hearts' watermelon plants at Charleston, S.C., and Clinton, N.C. Experiment 3.

\begin{tabular}{|c|c|c|c|c|}
\hline \multirow[b]{4}{*}{ Cultivar } & \multirow[b]{4}{*}{$\begin{array}{c}\mathrm{P} \\
\left(\mathrm{mg} \cdot \text { liter }^{-1}\right)\end{array}$} & \multirow{4}{*}{$\begin{array}{c}\frac{\text { Clinton }}{\text { Hollow }} \\
\text { heart } \\
(\%)\end{array}$} & \multicolumn{2}{|c|}{ Charleston } \\
\hline & & & & No. 2 \\
\hline & & & & $(\%)$ \\
\hline & & & $\begin{array}{c}\text { Fancy } \\
(\%)\end{array}$ & $\begin{array}{l}\text { Mean of both } \\
\text { cultivars }\end{array}$ \\
\hline \multirow[t]{3}{*}{ Queen of Hearts } & 5 & 21 & 50 & 16 \\
\hline & 15 & 18 & 43 & 21 \\
\hline & 45 & 7 & 44 & 7 \\
\hline Significance & & $\mathrm{Q}^{*}$ & NS & $\mathrm{Q}^{* *}$ \\
\hline \multirow[t]{3}{*}{ Crimson Sweet } & 5 & 7 & 53 & --- \\
\hline & 15 & 10 & 37 & --- \\
\hline & 45 & 16 & 68 & --- \\
\hline Significance & & $\mathrm{L}^{*}$ & $\mathrm{Q}^{* *}$ & \\
\hline \multicolumn{5}{|c|}{ Source of variation ${ }^{2}$} \\
\hline Replication & & 2 & 1 & 6 \\
\hline Cultivar (Cv) & & 1 & 0 & 4 \\
\hline $\mathrm{N}$ & & 3 & 4 & 0 \\
\hline $\mathrm{Cv} \times \mathrm{N}$ & & 2 & 2 & 1 \\
\hline $\mathrm{P}$ & & 0 & 11 & $15^{* *}$ \\
\hline $\mathrm{Cv} \times \mathrm{P}$ & & $13^{* *}$ & $8^{*}$ & 7 \\
\hline $\mathrm{N} \times \mathrm{P}$ & & 4 & 4 & 4 \\
\hline $\mathrm{Cv} \times \mathrm{N} \times \mathrm{P}$ & & 8 & 2 & 2 \\
\hline Error & & 67 & 68 & 62 \\
\hline
\end{tabular}

${ }^{2}$ Sum of squares for each factor converted to a percentage of total sum of squares.

${ }_{\text {ss, }, * * *}$ F test nonsignificant or significant at $P \leq 0.05$ or 0.01 , respectively; $\mathrm{L}=$ linear and $\mathrm{Q}=$ quadratic effect. Indicates significance of increasing $\mathrm{N}$ rate pooled over all $\mathrm{P}$ rates.

P seedling fertility can be used with 'Crimson Sweet' and 'Queen of Hearts' without any long-term detrimental effects on fruit yield or quality. Whether all seedless cultivars respond similarly to PNC is unknown. Commercial watermelon seedlings, conditioned during the greenhouse production phase with low $\mathrm{N}$ and $\mathrm{P}$, are easier to manage than those conditioned at higher levels. Based on these studies, we
College of Agriculture and Life Sciences. 1991. The 1991 North Carolina agriculture chemicals manual. North Carolina State Univ., Raleigh.

Cook, W. 1991. 1991 Agricultural chemicals handbook. Clemson Univ. Coop. Ext. Serv. EC 670.

Dufault, R.J. 1985. Relationship among nitrogen, phosphorus, and potassium fertility regimes on celery transplant growth. HortScience 20:11041106.

Dufault, R.J. 1986. Influence of nutritional conditioning on muskmelon transplant quality and early yield. J. Amer. Soc. Hort. Sci. 111:698703.

Elmstrom, G.W. and D.N. Maynard. 1990. Attraction of honey bees to watermelon with bee attractant. Proc. Fla. State Hort. Soc. 103:130133.

Hall, M.R. 1989. Cell size of seedling containers influences early vine growth and yield of transplanted watermelon. HortScience 24:771-773.

Henderson, W.R. 1977. Effect of cultivar, polyploidy and "reciprocal" hybridization on characters important in breeding triploid seedless watermelon hybrids. J. Amer. Soc. Hort. Sci. 102:293-297.

Ivanoff, S.S., R.C. Albritton, C.L. Blount, and B.E. Waggoner. 1960. Watermelon transplants for healthier, earlier and more profitable crops. Mississippi Agr. Expt. Sta. Bul. 588.

Knavel, D.E.. 1977. The influences of nitrogen on pepper transplant growth and yielding potential of plants grown with different levels of soil nitrogen. J. Amer. Soc. Hort. Sci. 102:533-535.

Lamb, M.J., G.C. Clough, and D.D. Hemphill, Jr. 1993. Pretransplant watermelon nutrition with various nitrate : ammonium ratios and supplemental calcium. HortScience 28:101-103.

Little, T.M. 1985. Analysis of percentage and rating scale data. HortScience 20:642-644.

Masson, J., N. Tremblay, and A. Gosselin. 1991. Effects of nitrogen fertilization and HPS supplementary lighting on vegetable transplants production. I. Transplant growth. J. Amer. Soc. Hort. Sci. 116:594-598.

Maynard, D. 1989. Triploid watermelon seed orientation affects seedcoat adherence on emerged cotyledons. HortScience 24:603-604.

Melton, R.R. and R.J. Dufault. 1991. Tomato seedling growth, earliness, yield, and quality following pretransplant nutritional conditioning and low temperatures. J. Amer. Soc. Hort. Sci. 116:421-425.

Mohr, H.C. 1986. Watermelon breeding, p. 37-66. In: M. Bassett (ed.). Breeding vegetable crops. AVI, Westport, Conn.

Nettles, V.F. 1963. Planting and mulching studies with cucurbits. Proc. Fla. State Hort. Soc. 76:178 182.

Tremblay, N., S. Yelle, and A. Gosselin. 1987. Effects of $\mathrm{CO}_{2}$ enrichment, nitrogen and phosphorus fertilization on growth and yield of celery transplants. HortScience 22:875-876.

U.S. Dept. of Agriculture. 1978. United States standards for grades of watermelons. U.S. Dept. Agr., Washington, D.C.

Vavrina, C.S., K. Armbrester, and T.B. Cole. 1990. Watermelon production as influenced by transplant age. Proc. Fla. State Hort. Soc. 103:94-96.

Aloni, B., T. Pashkar, and L. Karni. 1991. Nitrogen supply influences carbohydrate partitioning of pepper seedlings and transplant development. J. Amer. Soc. Hort. Sci. 116:995-999.
Weston, L.A. and B.H. Zandstra. 1989. Transplant age and $\mathrm{N}$ and $\mathrm{P}$ nutrition effects on growth and yield of tomatoes. HortScience 24:88-90. 